\title{
Pengaruh Pemberian Pendidikan Kesehatan tentang Perkembangan Penyakit Pasien terhadap Tingkat Kecemasan Keluarga ti Ruang ICU-ICCU RSUD Provinsi NTB Tahun 2019
}

\author{
Aan Dwi Sentana ${ }^{1(\mathrm{CA})}$, Nur Ita Pratiwi ${ }^{2}$ \\ ${ }^{1(\mathrm{CA})}$ Jurusan Keperawatan, Poltekkes Kemenkes Mataram, Indonesia; dwi_sentana@yahoo.co.id \\ ${ }^{2}$ Jurusan Keperawatan, Poltekkes Kemenkes Mataram, Indonesia
}

\begin{abstract}
Background: Anxious attitude is a response (presumption) of a person both in thoughts, actions and emotional conditions to certain events that might occur or are thought to occur in his life. There are several factors that cause families to feel anxious about the condition of patients being treated in the ICU, among them, the family fears that there will be disability in the patient, fear of loss, socio-economic problems, lack of providing information or health education from health workers. Based on several factors that influence the anxiety of the patient's family, the information provided in the form of health education is one very important thing. Objective: To determine the effect of providing health education about the development of patient's disease to the level of family anxiety. Method: The design of this study used Pre Experimental with (one group pre post test desig). The population in this study was a family with one of his family members being treated in the ICU-ICCU room at the NTB Provincial Hospital. This study used Purposive sampling and obtained 17 samples, the way of collecting data using questionnaires and data analysis using Wilcoxon Test. Results: Analysis of data before being given the most health education respondents experienced moderate anxiety, namely 11 respondents $(64.7 \%)$. After being given the most health education the respondents experienced mild anxiety, namely 9 respondents $(52.9 \%)$. The results of the study were obtained $(\mathrm{p}=0,000)$. Conclusion: There is an effect of the provision of health education about the development of patient's disease to the level of family anxiety in the ICU-ICCU room at the NTB Provincial Hospital
\end{abstract}

\section{Keywords: Health education, Family anxiety, Patient disease progression}

\begin{abstract}
ABSTRAK
Latar Belakang : Terdapat beberapa faktor yang menyebabkan keluarga merasa cemas dengan kondisi pasien yang dirawat di ICU diantaranya, keluarga takut akan terjadi kecacatan pada pasien, takut akan kehilangan, masalah sosial ekonomi, kurangnya pemberian sebuah informasi atau pendidikan kesehatan dari tenaga kesehatan. Berdasarkan beberapa faktor yang memepengaruhi kecemasan keluarga pasien tersebut, informasi yang diberikan berupa pendidikan kesehatan menjadi satu hal yang sangat penting. Tujuan : Mengetahui pengaruh pemberian pendidikan kesehatan tentang perkembangan penyakit pasien terhadap tingkat kecemasan keluarga. Metode : Desain penelitian ini mengunakan Pra Eksperimental (one group pre post test desig) dengan populasi adalah keluarga yang salah satu anggota keluarganya dirawat di ruang ICU-ICCU RSUD Provinsi NTB. Tehnik Sampling menggunakan Purposive sampling dan didapatkan 17 sampel, pengumpulan data menggunakan kuesioner dan di uji menggunakan Uji wilcoxon. Hasil : Data sebelum diberikan pendidikan kesehatan terbanyak responden mengalami kecemasan sedang yaitu 11 responden (64,7\%). Setelah diberikan pendidikan kesehatan terbanyak responden mengalami kecemasan ringan yaitu 9 responden $(52,9 \%)$. Hasil penelitian didapatkan $(\mathrm{p}=$ 0,000). Kesimpulan: Ada Pengaruh pemberian pendidikan kesehatan tentang perkembangan penyakit pasien terhadap tingkat kecemasan keluarga di ruang ICU-ICCU RSUD Provinsi NTB
\end{abstract}

Kata Kunci : Pendidikan kesehatan, Kecemasan keluarga, Perkembangan penyakit 


\section{PENDAHULUAN}

Kecemasan merupakan sebuah perasaan yang dialami oleh seseorang individu dan bersifat subjektif yang tidak dapat diamati secara langsung. Kecemasan biasanya berhubungan dengan sebuah situasi yang bersifat mengancam atau membahayakan, dan biasanya dengan berjalanya waktu keadaan cemas tersebut akan teratasi sendiri. Sikap cemas merupakan respon (anggapan) seseorang baik dalam pikiran, tindakan dan kondisi emosional terhadap peristiwa tertentu yang mungkin terjadi atau dianggap akan terjadi dalam hidupnya. Rasa cemas ini biasanya bersumber dari perasaan khawatir terhadap sesuatu. Meskipun rasa cemas dapat ditimbulkan oleh masalah kecil, sepele dan terkadang hanya khayalan saja namun secara umum cemas ditimbulkan oleh karena adanya masalah yang besar, hal-hal yang dianggap penting dalam kehidupan yang memang dalam kenyataanya sudah atau akan terjadi (Riyadi, 2009)

Keadaan sakit merupakan keadaan patologis yang terjadi baik fisik maupun psikis dan sakit menjadi salah satu penyebab terjadinya kecemasan pada individu maupun keluarga terlebih dengan kondisi sakit terminal dan dirawat diruang perawatan kritis. Intensive Care Unit (ICU) dan Intensive Cardiac Care Unit (ICCU) merupakan unit dirumah sakit yang berfungsi untuk merawat pasien dengan keadaan kritis. Unit ini berbeda dengan unit-unit yang lainnya, karena selain pasien dirawat oleh perawat terlatih atau tim medis khusus untuk pasien kritis, juga dalam merawat pasien, perawat untuk satu atau dua pasien dalam setiap shifnya. Selain itu kunjungan keluarga terhadap pasien juga dibatasi dan berbeda dengan unit lainnya sehingga keluarga akan mengalami keadaan depresi, kecemasan bahkan trauma setelah anggota keluarganya dirawat di ruang ICU (Rab, 2007)

Prevalansi anggota keluarga dengan pasien kritis yang mengalami kecemasan dari beberapa penelitian rata-rata adalah 35\%-73\%. Penelitian Lain menunjukkan tingkat kecemasan keluarga pasien kritis dari tingkat kecemasan sedang sampai berat (McAdam \& Puntillo, 2009). Sejalan dengan penelitian dilakukan oleh sugimin (2017) menggambarkan bahwa Respon Maladaptif Fisiologis lebih besar dari pada respon Adaptif. Penelitian lain yang dilakukan oleh Ezy (2016) menunjukka bahwa ada hubungan kebutuhan keluarga pasien dengan tingkat kecemasan $(\mathrm{p}=0,017)$

Peran anggota keluarga dalam peran hidup-mati-sakit orang yang dicintai mengancam kesejahteraan keluarga dan dapat memicu respon stres pasien dan keluarga. Keluarga memasuki situasi yang tidak terencana ini dengan hasil yang tidak terduga dan sering kali dipaksa untuk menjalani peran mengambil keputusan. Kecemasan yang diperlihatkan oleh anggota keluarga pasien adalah akibat yang diperkirakan dari aktivitas respons stres, suatu mekanisme yang bersifat sedikit protektif dan adaptif yang dipicu oleh sistem neuroendokrin sebagai respons terhadap stressor (Morton, 2012)

Terdapat beberapa faktor yang menyebabkan keluarga merasa cemas dengan kondisi pasien yang dirawat di ICU diantaranya, keluarga takut akan terjadi kecacatan pada pasien, takut akan kehilangan, masalah sosial ekonomi, kurangnya pemberian sebuah informasi atau pendidikan kesehatan dari tenaga kesehatan (Rahmatiah, 2012).

Berdasarkan beberapa faktor yang memepengaruhi kecemasan keluarga pasien tersebut, informasi yang diberikan berupa pendidikan kesehatan menjadi satu hal yang sangat penting. Pendidikan kesehatan pada hakekatnya adalah suatu kegiatan atau usaha individu untuk menyampaikan informasi (transfer of knowledge) lebih khususnya pesan kesehatan kepada masyarakat, kelompok, individu dengan harapan 
bahwa dengan adanya peran tersebut, masyarakat kelompok dan individu dapat menumbuhkan pengetahuan tentang kesehatan, dan pengetahuan tersebut diharapkan berpengaruh terhadap perilakunya dengan kata lain pendidikan tersebut dapat membawa akibat terhadap perubahan perilaku sasaran (Indrayani, 2012).

Dapat dikatakan dukungan informasi yang jelas dan akurat dari tenaga medis berkaitan dengan adanya penyakit yang diderita oleh pasien beserta tindakan yang dapat diambil untuk keselamatan pasien. Henneman and Cardin (dalam Urden \& Stacy, 2000) yaitu salah satu kebutuhan anggota keluarga pasien kritis adalah kebutuhan akan informasi, jenis informasi yang dibutuhkan keluarga dari perawat berhubungan dengan perkembangan penyakit pasien.

Berdasarkan latar belakang tersebut penulis tertarik melakukan penelitian dengan judul " Pengaruh pemberian pendidikan kesehatan tentang perkembangan Penyakit pasien terhadap tingkat kecemasan keluarga di ruang ICU-ICCU RSUD Provinsi NTB”. Tujuan dari penelitian ini adalah untuk mengetahui pengaruh pemberian pendidikan kesehatan tentang perkembangan penyakit pasien terhadap tingkat kecemasan keluarga di ruang ICU-ICCU RSUD Provinsi NTB.

\section{METODE}

Desain atau rancangan yang digunakan dalam penelitian ini adalah Pra Eksperimental dengan one group pre post test design yakni suatu rancangan penelitian dimana objek penelitian dilakukan pretest terlebih dahulu sebelum diberikan perlakuan kemudian setelah diberikan perlakuan lalu dilakukan postest (Wasis, 2008). Peneliti ini adalah penelitian yang bersifat komparatif yaitu suatu penelitian yang dilakukan untuk membandingkan yaitu pre dan post pendidikan kesehatan, menggunakan dua sampel yang berpasangan sehingga uji data yang digunakan adalah uji Wilcoxon (Wasis, 2008). Taraf signifikansi yang digunakan dalam penelitian ini adalah $\alpha=0,05$. Artinya jika taraf signifikansi kurang dari taraf nyata $(0,05)$ maka terdapat pengaruh perlakuan pendidikan kesehatan yang diberikan dengan penurunan kecemasan, sebaliknya jika taraf signifikansi sama atau lebih besar dari taraf nyata maka tidak terdapat pengaruh antara pendidikan kesehatan yang diberikan dengan penurunan kecemasan keluarga pasien yang dirawat di ruang ICU-ICCU Rumah Sakit Umum Daerah Provinsi NTB.

\section{HASIL}

1. Karakteristik responden

Tabel 1. Karakteristik Responden di Ruang di ICU-ICCU RSUD Provinsi NTB, 2019 (n=17)

\begin{tabular}{cccc}
\hline No & \multicolumn{1}{c}{ Karakteristik } & Frekwensi & \% \\
\hline 1. & Golongan Umur (tahun) : & 6 & \\
& $-\quad$ 17-25 (Remaja akhir) & 4 & 35.3 \\
& $-\quad 26-35$ (dewasa awal) & 4 & 23.5 \\
& - 36-45 (dewasa akhir) & 2 & 23.5 \\
& - 46-55 (lansia awal) & 1 & 11.8 \\
& - 56-65 (lansia akhir) & & 5.9 \\
\hline 2. & Jenis Kelamin & 9 & 52.9 \\
& - Laki-Laki & 8 & 47.1 \\
\hline
\end{tabular}


Sentana, Pratiwi, (2019).

\begin{tabular}{clcc}
\hline No & \multicolumn{1}{c}{ Karakteristik } & Frekwensi & \% \\
\hline 3. & Tingkat Pendidikan & 13 & \\
& - Pendidikan Menengah & 4 & 76.5 \\
& $-\quad$ Pendidikan Tinggi & & 23.5 \\
\hline 4. & Pekerjaan & 10 & \\
& - Bekerja & 7 & 58.8 \\
& - Tidak bekerja & & 41.2 \\
\hline 5. & Hubungan dengan pasien & 3 & 17.6 \\
& - Suami/istri & 1 & 5.9 \\
& - Orang Tua & 13 & 76.5 \\
\hline
\end{tabular}

Tabel 1 diatas menunjukkan bahwa paling banyak responden berusia 17-25 tahun (35,3\%), berjenis kelamin laki-laki (52,9\%), tingkat pendidikan menengah $(76,5 \%)$, berkerja $(58,8 \%)$ serta memiliki hubungan dengan pasien sebagai anak $(76,5 \%)$.

2. Tingkat kecemasan

Tingkat kecemasan responden sebelum dan sesudah diberikan pendidikan kesehatan dapat dilihat pada tabel 2 berikut.

Tabel 2. Tingkat kecemasan keluarga pasien sebelum dan sesudah diberikan pendidikan kesehatan di Ruang ICU-ICCU RSUD Provinsi NTB, 2019 ( $\mathrm{n}=17)$

\begin{tabular}{llcccc}
\hline \multirow{2}{*}{ No } & \multirow{2}{*}{ Tingkat Kecemasan } & \multicolumn{2}{c}{ Sebelum Perlakuan } & \multicolumn{2}{c}{ Sebelum Perlakuan } \\
\cline { 3 - 5 } & & $\mathrm{n}$ & $\%$ & $\mathrm{n}$ & $\%$ \\
\hline 1. & Tidak Cemas & 0 & 0 & 1 & 5.9 \\
2. & Cemas Ringan & 1 & 5.9 & 9 & 52.9 \\
3. & Cemas Sedang & 11 & 64.7 & 6 & 35.3 \\
4. & Cemas Berat & 5 & 29.4 & 1 & 5.9 \\
\hline \multicolumn{7}{c}{ p-value $=0,001$} \\
\hline
\end{tabular}

Tabel 2 menggambarkan bahwa sebelum dilakukan pendidikan kesehatan terbanyak responden mengalami kecemasan sedang $(64,7 \%)$ sedangkan setelah diberikan pendidikan kesehatan terbanyak mengalami kecemasan ringan $(52,9 \%)$.

\section{PEMBAHASAN}

\section{Tingkat Kecemasan Sebelum Dilakukan Pendidikan Kesehatan}

Hasil tabulasi yang telah dilakukan oleh peneliti dengan cara menyebar kuesioner ke 17 responden di dapatkan data bahwa sebelum dilakukan pendidikan kesehatan terbanyak responden mengalami kecemasan sedang sebanyak 11 responden $(64,7 \%)$.

Hasil penelitian yang dilakukan oleh Madianingsih yang berjudul "Gambaran Kecemasan Keluarga Pasien Di Instalasi Gawat Darurat (Igd) Rsud Wates Kulon Progo" kecemasan sedang sebagian besar dialami oleh remaja akhir (17-25 tahun). Penelitian ini Sejalan dengan penelitian Sugimin (2017) menyatakan bahwa usia terbanyak responden pada rentang usia remaja akhir (17-25 tahun) yaitu mengalami cemas sedang. Menurut teori Kaplan \& Sadock (1998) berpendapat bahwa faktor usia muda lebih mudah mengalami cemas daripada usia tua. Semakin muda usia seseorang 
dalam menghadapi masalah maka akan sangat memengaruhi konsep dirinya. Usia dipandang sebagai suatu keadaan yang menjadi dasar kematangan dan perkembangan seseorang. Hal ini terjadi karena pada usia 30-50 tahun, seseorang sudah matang dalam berfikir dan menghadapi masalah. Sedangkan semakin rendah usia seseorang yaitu < 30 tahun maka semakin tinggi tingkat kecemasan yang dialaminya serta kematangan individu dapat dilihat langsung secara objektif dengan periode usia, sehingga berbagai proses pengalaman, pengetahuan, keterampilan, kemandirian terkait sejalan dengan bertambahnya usia individu dan ketidakcemasan yang dialami keluarga pasien di ruang gawat darurat maupun kritis juga dapat disebabkan oleh koping keluarga yang cukup baik yaitu mengenai pemberian informasi tentang kondisi pasien(Lestari,2015).

Berdasarkan hasil penelitian yang dilakukan oleh Madianingsih yang berjudul "Gambaran Kecemasan Keluarga Pasien Di Instalasi Gawat Darurat (Igd) Rsud Wates Kulon Progo" di dapatkan hasil bahwa perempuan lebih banyak mengalami kecemasan sedang daripada laki-laki. Penelitian ini sejalan dengan Sugimin (2017) menunjukkan bahwa kecemasan sebagian besar dialami oleh responden berjenis kelamin perempuan sebanyak 16 responden (53,3\%), dalam penelitiannya mengatakan bahwa perempuan memiliki sifat keibuan, telaten, perhatian, lembut sehingga lebih nyaman bila pasien ditunggu seorang perempuan. Myers (1983) dalam Trismiati (2006) mengatakan bahwa perempuan lebih cemas akan ketidakmampuannya dibanding dengan laki-laki, dikarenakan laki-laki lebih aktif sedangkan perempuan lebih sensitif. Penelitian ini menunjukkan bahwa laki-laki lebih rileks dan tenang dibanding perempuan.

Pendidikan responden yang sebagian besar SMA (78,5\%) dibandingkan perguruan tinggi $(23,5)$ juga mempengaruhi tingkat kecemasan keluarga. Sejalan dengan penelitian Toulasik \& Maria (2013) tingkat kecemasan sedang lebih banyak dialami oleh responden dengan pendidikan SMA $(42,1 \%)$. Menurut teori Notoadmodjo semakin tinggi tingkat pendidikan maka semakin mudah seseorang menerima hal baru dan akan mudah menyesuaikan diri. Tingkat pendidikan seseorang atau individu akan berpengaruh terhadap kemampuan berfikir, semakin tinggi tingkat pendidikan akan semakin mudah berfikir secara rasional dan menangkap informasi baru termasuk dalam menguraikan masalah baru (Stuart,2016).

Menurut penelitian yang dilakukan Isnani (2013) yang berjudul "Faktor-Faktor yang Mempengaruhi Tingkat Kecemasan Keluarga Pasien yang Dirawat di Ruang ICU RSUD Dr. M.M Dunda Limboto" di dapatkan bahwa responden yang bekerja memiliki tingkat kecemasan berat yang relatif tinggi dari pada responden yang tidak bekerja, menurut peneliti hal ini disebabkan banyak faktor yang dpat menyebabkan kecemasan salah satunya seperti kurangnya informasi.

Selain itu hungan dengan pasien juga mempengaruhi tingkat kecemasan. Dalam penelitian Rahayu (2016) menyebutkan bahwa jika yang sakit adalah anggota keluarga inti yaitu anak, ayah, ibu maka responden akan mempunyai tingkat cemas yang lebih tinggi dibanding dengan anggota keluarga yang lain. Respon cemas yang lebih tinggi kepada keluarga inti karena adanya kedekatan emosional yang lebih tinggi dibandingkan dengan anggota keluarga yang lain. Kecemasan terjadi karena ikatan antara anak dan orangtua sangat kuat ikatan emosionalnya. Anak merupakan buah dari pernikahan dari kedua orang tua yang biasanya memiliki emosional yang kuat terhadap orang tua (Setiawati, B. 2009). 


\section{Tingkat Kecemasan Sesudah Dilakukan Pendidikan Kesehatan}

Hasil olah data yang dilakukan oleh peneliti setelah responden mendapatkan perlakuan pendidikan kesehatan didapatkan data bahwa responden mengalami penurunan tingkat kecemasan menjadi kecemasan ringan sebanyak 9 responden $(52,9)$.

Kecemasan yang terjadi karena kurangnya informasi mengalami penurunan setelah pemberian informasi. Segala bentuk informasi yang diberikan, pengetahuan yang diberikan, diharapkan dapat berpengaruh pada perubahan dalam tingkat kecemasan. Pengetahuan tentang kesehatan diharapkan dapat berpengaruh terhadap perilakunya, dengan kata lain pendidikan tersebut dapat membawa akibat terhadap perubahan perilaku sasaran (Notoatmodjo, 2003).

Salah satu tindakan untuk mengurangi tingkat kecemasan adalah dengan cara mempersiapkan mental dari klien. Persiapan mental tersebut salah satunya dapat dilakukan melalui pendidikan kesehatan (Health education). Kemampuan perawatan untuk mendengarkan secara aktif untuk pesan baik verbal dan nonverbal sangat penting untuk membangun hubungan saling percaya dengan pasien dan keluarga

Penelitian yang dilakukan oleh Lukman, Sumitro Adi Putra dan Azwadi (2010) dengan judul pengaruh pendidikan kesehatan terhadap kecemasan pasien preoperasi di Rumah Sakit dr. Mohammad Hoesin Palembang “ didapatkan hasil bahwa dari sampel sebanyak 32 responden sebelum dilakukan pendidikan kesehatan rata-rata mengalami kecemasan sedang dengan jumlah 19 responden $(59,4 \%)$ dan setelah diberikan pendidikan kesehatan rata-rata responden mengalami kecemasan dengan kategori cemas ringan yaitu sebanyak 16 responden (50\%). Hal ini menandakan bahwa pendidikan kesehatan dapat menurunkan tingkat kecemasan.

Pendidikan kesehatan adalah proses penyampaian informasi dan pengetahuan (Transfer of Knowledge) dengan tujuan agar informan bisa mendapatkan sebuah informasi sehingga pengetahuanya menjadi meningkat (Pertiwi, 2012). Menurut teori Hawari (2011) Informasi adalah pemberitahuan yang dibutuhkan keluarga mengenai semua hal yang berhubungan dengan pasien. Kebutuhan akan informasi meliputi informasi tentang perkembangan penyakit pasien, kondisi sesungguhnya mengenai perkembangan penyakit pasien, kondisi pasien setelah dilakukan tindakan/ pengobatan, rencana dirawat atau boleh pulang.

Menurut penelitian yang dilakukan oleh Imran Jum Wahab dengan judul "Faktor-Faktor Yang Berhubungan Dengan Tingkat Kecemasan Pada Pasien Pre Operasi Di Ruang Bedah Rsud Labuang Baji Makassar" didapatkan hasil bahwa ada hubungan yang bermakna antara pengetahuan dengan tingkat kecemasan.

Penurunan tingkat kecemasan keluarga tersebut tidak terlepas dari pendidikan kesehatan yang diberikan peneliti kepada keluarga pasien sesuai dengan kebutuhan keluarga yaitu berupa informasi, hal ini selaras dengan pendapat menurut CCFNI (critical care family need inventory) dalam Nursalam (2015) kebutuhan keluarga dengan pasien kritis adalah salah satunya kebutuhan informasi yang terdiri dari mengetahui perkembangan penyakit pasien.

Selain itu penerimaan informasi yang baik dari responden mempercepat pemahaman dan menambah pengetahuan keluarga tentang perkembangan penyakit pasien sehingga tingkat kecemasan keluarga mengalami penurunan. 


\section{Pengaruh pendidikan kesehatan tentang perkembangan penyakit pasien terhadap tingkat kecemasan keluarga di ruang ICU-ICCU RSUD Provinsi NTB}

Berdasarkan analisa data dari kuesioner yang disebarkan peneliti kepada 17 responden pada bulan April 2019 dengan menggunakan uji wilcoxon didapatkan hasil test statistic exact sig ( 2 tailed $)=0,000$ lebih kecil dibandingkan taraf nyata $(\alpha=0,005)$ yang artinya ada pengaruh yang signifikan tingkat kecemasan keluarga pasien sebelum dilakukan dan sesuadah dilakukan pendidikan kesehatan tentang perkembangan penyakit pasien di ruang ICU-ICCU RSUD Provinsi NTB. Artinya bahwa sebanyak 17 responden mengalami penurunan tingkat kecemasan setelah diberikan perlakuan berupa pendidikan kesehatan tentang perkembangan penyakit pasien di ruang ICU-ICCU RSUD Provinsi NTB.

Penurunan tingkat kecemasan keluarga tersebut tidak terlepas dengan pendidikan kesehatan yang diberikan peneliti kepada keluarga pasien berupa Perkembangan penyakit pasien yang terdiri dari Pola tidur, tanda-tanda vital serta Pola kenyamanan pasien. Penerimaan Informasi yang baik oleh keluarga pasien menjadi sebuah pemahaman yang positif akan hal-hal yang berkaitan dengan Perkembangan Penyakit pasien yang dirawat di Ruang ICU-ICCU sehingga menjadi pengetahuan keluarga pasien terkait perkembangan penyakit pasien menjadi lebih baik. Berdasarkan wawancara dengan dengan keluarga pasien didapatkan data bahwa sebelum diberikan pendidikan kesehatan terkait perkembangan penyakit pasien beberapa keluarga mengatakan tidak mengetahui perkembangan penyakit keluarganya karena tidak diberitahu oleh petugas bahkan masih banyak keluarga yang beranggapan bahwa keluarganya yang di rawat di ruang ICU-ICCU mempunyai prognosis yang jelek dan mengalami kondisi yang sangat buruk dan sedikit kemungkinan untuk sembuh. Namun setelah diberikan pendidikan kesehatan tentang perkembangan penyakit pasien, keluarga mengatakan merasa lebih tenang, lebih paham dengan kondisi keluarganya sekarang, mereka lebih paham khususnya tentang Pola tidur pasien, tandatanda vitalnya serta pola nyamanyan pasien dan pemahaman tersebut berdampak pada penurunan tingkat kecemasan dari keluarga pasien.

Sesuai dengan penelitian yang dilakukan oleh Isnai Nurulhuda Rahmatiah dengan judul “ faktorfaktor yang mempengaruhi tingkat kecemasan keluarga pasien yang dirawat di ruang ICU RSUD Dr. M. M. Dundo Limboto" bahwa informasi merupakan faktor yang sangat berpengaruh terhadap tingkat kecemasan seseorang.

Informasi yang diberikan oleh peneliti kepada responden atau keluarga pasien berupa Pola tidur pasien, tanda-tanda vital serta pola kenyamanan pasien hal ini sesuai dengan pendapat Henneman and Cardin (dalam Urden \& Stacy, 2000) yaitu salah satu kebutuhan anggota keluarga pasien kritis adalah kebutuhan akan informasi, jenis informasi yang dibutuhkan keluarga dari perawat berhubungan dengan perkembangan penyakit pasien. Keluarga ingin mendapatkan informasi tentang tanda-tanda vital (stabil vs tidak stabil), tingkat kenyamanan pasien, dan pola tidur.

\section{KESIMPULAN}

Tingkat kecemasan responden sebelum diberikan pendidikan kesehatan paling banyak mengalami kecemasan sedang. Tingkat kecemasan responden sesudah diberikan pendidikan kesehatan terbanyak 
mengalami kecemasan ringan. Terdapat pengaruh yang signifikan pemberian pendidikan kesehan terhadap tingkat kecemaan keluarga pasien yang dirawat di ruang ICU-ICCU RSUD Provinsi NTB.

\section{DAFTAR PUSTAKA}

Aprina Madianingsih. 2017. Gambaran Kecemasan Keluarga Pasien Di Instalasi Gawat Darurat (Igd) Rsud Wates Kulon Progo, http://repository.unjaya.ac.id/2098/, diperoleh tanggal 20 juni 2019 jam 20:00 Wita

Dharma, Kelana K. 2001. Metodologi Pendidikan Keperawatan. Jakarta: Trans Info Media.

Effendi dan Makhfudli. F, 2009. Keperawatan kesehatan komunitas: Teori dan praktik dalam keperawatan. Jakarta: Salemba medika

Gangka, Yesi. 2013. Faktor yang berhubungan dengan tingkat kecemasan pasien preoperasi bedah mayor digestif di RSUP $d r$. Wahidin Sudiro Husodo Makasar, http://ejournal.stikesnh.ac.id/index.php/jikd/article/view/420. diperoleh tanggal 19 Juni 2019 pukul 20.05 WITA.

Gunarsa, Singgih, D. 2008. Psikologi Perkembangan Anak dan Remaja. Jakarta: Gunung Mulia

Hawari, D. 2011. Managemen Stress, Cemas dan Depresi, Fakultas Kedokteran Universitas Indonesia, Jakarta.

Henneman \& Cardin. 2002. Family Centered Critical Care a Practical Appoarch to Making it Happen Diambil tanggal 12 Oktober 2018 dari http://ccn.aacnjournals.org

Herawani, I, et all .2001. Pendidikan Kesehatan Dalam Keperawatan. Jakarta: EGC

Heri D. J. Maulana. 2009. Promosi Kesehatan. Editor: Egi Komara Yudha. Jakarta: EGC.

Hidayat, A. A. A. (2006). Kebutuhan Dasar Manusia, Aplikasi Konsep dan Proses Keperawatan. Jakarta: Salemba Medika.

Indrayani, A \& Agus Santoso. 2012, Hubungan Pendidikan Kesehatan Dengan Kecemasan Orang Tua Pada Anak Hospitalisasi. Skripsi. Universitas Diponegoro: Semarang

Jones, Rhonda. 2008. General Assessment and Vital Sign https://med.unhas.ac.id/fisioterapi/wpcontent/uploads/2016/11/PEMERIKSAAN-VITAL-SIGN.pdf . di akses Tanggal 12 Oktober 2018

Kaplan \& Sadock. 1998. Sinopsis Psikiatri Ilmu Pengetahuan Perilaku Psikiatr Klinis, Edisi VII Jilid II, Bina Aksara, Jakarta.

Lestari, T. 2015. Kumpulan Teori untuk Kajian Pustaka Penelitian Kesehatan, Nuha Medika, Yogyakarta

Manurung, Nixson, 2006. Terapi Reminiscence. Jakarta: CV Info Media

McAdam, J.L., \& Puntilo, K. 2009. Symtoms experienced by family members of patients in intensive care unit. American journal of critical care, 18 (3) : 200-210 https://www.ncbi.nlm.nih.gov/pubmed/19411580. Di akses pada tanggal 15 april 2019

Morton, Patricia G., Dorrie, F, dkk. 2012. Keperawatan Kritis. Jakarta: EGC

Mubarok, I, et all. 2007. Promosi kesehatan: Sebuah pengantar Proses Belajar Mengajar Dalam Pendidikan. Edisi pertama. Yogyakarta: Graha Ilmu. 
Murwarni, Arita. 2009. Pengantar Konsep Dasar Keperawatan. Yogyakarta: Fitramaya

Notoatmodjo, S. 2007. Pendidikan dan Perilaku Kesehatan, Rineka Cipta. Jakarta

Notoatmodjo, Soekidjo. 2003. Pendidikan dan Perilaku Kesehatan. Rineka Cipta. Jakarta

Nursalam \& Ferry, E. 2009. Pendidikan dalam keperawatan. Jakarta: Salemba Medika

Nursalam, 2015. Metodologi Penelitian Ilmu Keperawatan Pendekatan Praktis Edisi 3. Jakarta: Salemba Medika

Nursalam. 2009. Konsep dan penerapan metodologi penelitian ilmu keperawatan: Pedoman skripsi, tesis dan instrument penelitian keperawatan. Jakarta: Salemba Medika.

Rab, T. 2007. Agenda Gawat Darurat (Critical Care) Jilid I Edisi 2. Bandung: PT Alumni

Rahayu, K.I.N., 2016. Hubungan Antara Komunikasi Teraupetik dengan Tingkat Kecemasan Keluarga Pasien di ruang Intensive Care Unit, Journal of Nursing Care \& Biomolecular, Fakultas Ilmu Kesehatan Universitas Kadiri, file://C:/Users/USER/Downloads/5-98-1-PB\%20(1).pdf, diakses pada tanggal 20 Juni 2019.

Rahmatiah, I. N. 2013. Faktor-faktor yang Mempengaruhi Tingkat Kecemasan Keluarga Pasien yang di rawat di Ruang ICU RSUD Dr. M M Dunda. Limboto, http: // kim. ung. ac. id/ index. php/ KIMFIKK/ article/ view/ 2807/ 2783 diperoleh tanggal 8 oktober 2018 pukul 20.05 WITA

Riwidikdo, H. 2010. Statistik Kesehatan. Yogyakarta: Mitra Candikia Press

Riyadi, S dan Purwanto, T. 2009. Asuhan keperawatan Jiwa. Jogjakarta: Graha Ilmu

Rochman, K,L, 2010. Kesehatan Mental. Purwokerto: Fajar Media Press

Setiadi. 2007. Konsep dan Penulisan Riset Keperawatan. Yogyakarta: Graha Ilmu

Stuart, G.W. 2016. Principles and Practice of Psychiatric Nursing, 10th, diterjemahkan ke Bahasa Indonesia oleh Keliat B.A \& Pasaribu, J.,Elsevier, Singapore Pte Ltd.

Sugimin . 2017. Kecemasan Keluarga Pasien di ruang Intensive Care Unit Rumah Sakit Umum Pusat Dokter Soeradji Tirtonegoro Klaten, Skripsi, PSIK Universitas Muhammadiyah Surakarta.

Sunaryo. 2004. Psikologi untuk Keperawata. Jakarta: EGC

Trismiati. 2004. Perbedaan Tingkat Kecemasan Antara Pria Dan Wanita Akseptor Kontrasepsi Mantap Di RSUP Dr. Sardjito Yogyakarta. Jurnal Psyche. Vol 1:4-6

Urden \& Stacy, 2000. Priorities in Critical Care Nursing, 3RD Edition. Missouri: Mosby

Wahab, M. Imran Jum. 2010. Faktor-faktor yang Berhubungan dengan Tingkat Kecemasan pada Pasien Pra Operasi di Ruang Bedah RSUD Labuang Baji Makassar. Undergraduate (S1) thesis, Universitas Islam Negeri Alauddin Makassar. http://repositori.uin-alauddin.ac.id/3663/, diperoleh tanggal 20 Juni 2019 